\title{
A virtuális és geográfiai terek tulajdonságainak hatása a közösségekre
}

Az információs társadalom kommunikációs technológiái a megszokott térbeli és időbeli korlátok ledöntésével úfajta viselkedést tesznek lehetővé a társadalmi interakciók során is. Az információs technológia mai világában hipertextes szerveződésen alapuló olyan külső téri reprezentációk jelennek meg, melyek új, online közösségeknek otthont adó társadalmi környezetet teremtenek. Ma már igen sok tudományos kutatási eredmény bizonyítja, hogy a kibertér nemcsak az információáramlásban játszik nagy szerepet, hanem mind az online, mind pedig az offline társadalmi kapcsolatok alakulását is jelentősen befolyásolja. A cikk amellett érvel, hogy kevésbé valószínú azoknak a félelmeknek a beigazolódása, amelyek a kiberközösségeknek az együtt élő közösségekre gyakorolt egyoldalú, és a technológiai fejlődéssel egyre erősödő szétziláló hatásával kapcsolatban gyakran megfogalmazódnak. Az együtt élő közösségek és a geográfiai helyek kibertéri entitásokkal történő lényegi helyettesítése egyelőre, a jelenlegi technológiák biztosította „hely” és „jelenlét” mellett negatív utópiának tünik.

\section{Szerzői információ:}

\section{Vörös Zsófia \\ Közgazdász. 1998-ban végzett a Pécsi Tudományegyetem Közgazdaságtudományi Karán. 2002- tôl a Budapesti Múszaki és Gazdaságtudományi Egyetem múszaki menedzsment, gazdálkodás- és szervezéstudományi doktori iskolájának hallgatója. Speciális szakterülete az információme- nedzsment, kutatási területe a téri tájékozódás az információs technológia által létrehozott hipertextes szervezốdésú világokban.}

Így hivatkozzon erre a cikkre:

Vörös Zsófia. „A virtuális és geográfiai terek tulajdonságainak hatása a közösségekre”. Információs Társadalom V, 4. szám (2005): 72-91.

$=\quad$ https://dx.doi.org/10.22503/inftars.V.2005.4.6 $\rightleftharpoons$

A folyóiratban közölt müvek

a Creative Commons Nevezd meg! - Ne add el! - Így add tovább! 4.0

Nemzetközi Licenc feltételeinek megfelelöen használhatók. 
Vörös Zsófia

\section{A virtuális és geográfiai terek tulajdonságainak hatása a közösségekre}

\section{Apropó}

A 20. században tömegesen váltak ismertté az új kommunikációs eszközök, a társadalom múködésmódjának átalakulását ösztönzố új hálózati technológia bevonult hétköznapjainkba. A technológiák állandó fejlődése indukálja a kérdést, hogy ezek az új eszközök s az általuk lehetôvé vált új közlési módok mennyire hatnak a társadalmi folyamatokra.

Az információs technológia mai világában a klasszikus külsố téri reprezentációktól eltérő új, hipertextes szervezódésen alapuló külsố téri reprezentációk jelennek meg, melyek új közösségek ébredését teszik lehetôvé, továbbá befolyásolják az együtt élố közösségek kialakulását, dinamikáját is, gyakran megváltoztatva ezzel a különbözó társadalmi formációkat jelölő kifejezések - köztük a közösség - jelentését.

A World Wide Webet is felépítô hiperdokumentumok szavak és képek csoportjait számtalan útvonallal, kapcsolóelemmel összekötő, nyitott információs egységek, melyeket általában a link, a csomópont, az útvonal és a hálózat kifejezésekkel szokás leírni. A nem lineáris és nem szekvenciális hiperdokumentumok virtuális tereket definiálnak, melyeket hipertérnek vagy - William Gibson „Neurománc” címú könyve nyomán kibertérnek szoktak nevezni.

A kibertér információs és kommunikációs technikája újfajta tér-idố viszonyokat alakít ki, és ezáltal új lehetôségeket kínál az ember számára a tér felhasználásában. A kibertér megismerése, téri alakzatainak és tulajdonságainak meghatározása azonban meglehetôsen bonyolult feladat, mivel a teret ebben az esetben mesterségesen létrehozott geometriai formációk sokasága alkotja. K. Memarzia (1997) a kiberteret így jellemzi: „A kibertérben nincsenek fizikai akadályok, korlátok, hogy az ábrázolt virtuális térre dinamikát vagy térbeli és idóbeli előnyös tulajdonságokat kényszerítsenek rá. A kibertérben nem létezik nehézségi erố vagy súrlódás, csak ha előzóleg megtervezték, és meg is csinálták. [...] A kibertér nem korlátozódik három dimenzióra, mivel bármely kétdimenziós síkból vagy akár egy pontból is kibontakozhat egy újabb, sokdimenziós térbeli környezet. [...] A virtuális környezetben arra sincsenek szabályok, hogy a különbözố nagyságrendek (méretcsoportok) egymáshoz való aránya nem változhat. Sốt a környezetnek a használóhoz viszonyított arányait is tetszés szerint változtatni lehet... A kibertér lehet nem folyamatos, sokdimenziós és önmagába visszatéró. [...] Általában a kibertérben a valóságos tér minden alapelvét meg lehet sérteni, és tulajdonságait és korlátait csak a kifejezetten erre a digitális térre érvényes részletes elôirások és szabályozások szabják meg."1

\footnotetext{
${ }^{1}$ Memarzia, K. (1997): Towards the Definition and Applications of Digital Architecture. http://www.shef.ac.uk/students/ar/ara92km/thesis/. Idézi: Mészáros R. (2001).
} 
A kibertér médiuma, az internet osztott hálózatát mutatja az azt alkotó számítógépeket, valamint a köztük lévő kapcsolatokat szemléltetố 1 . ábra.

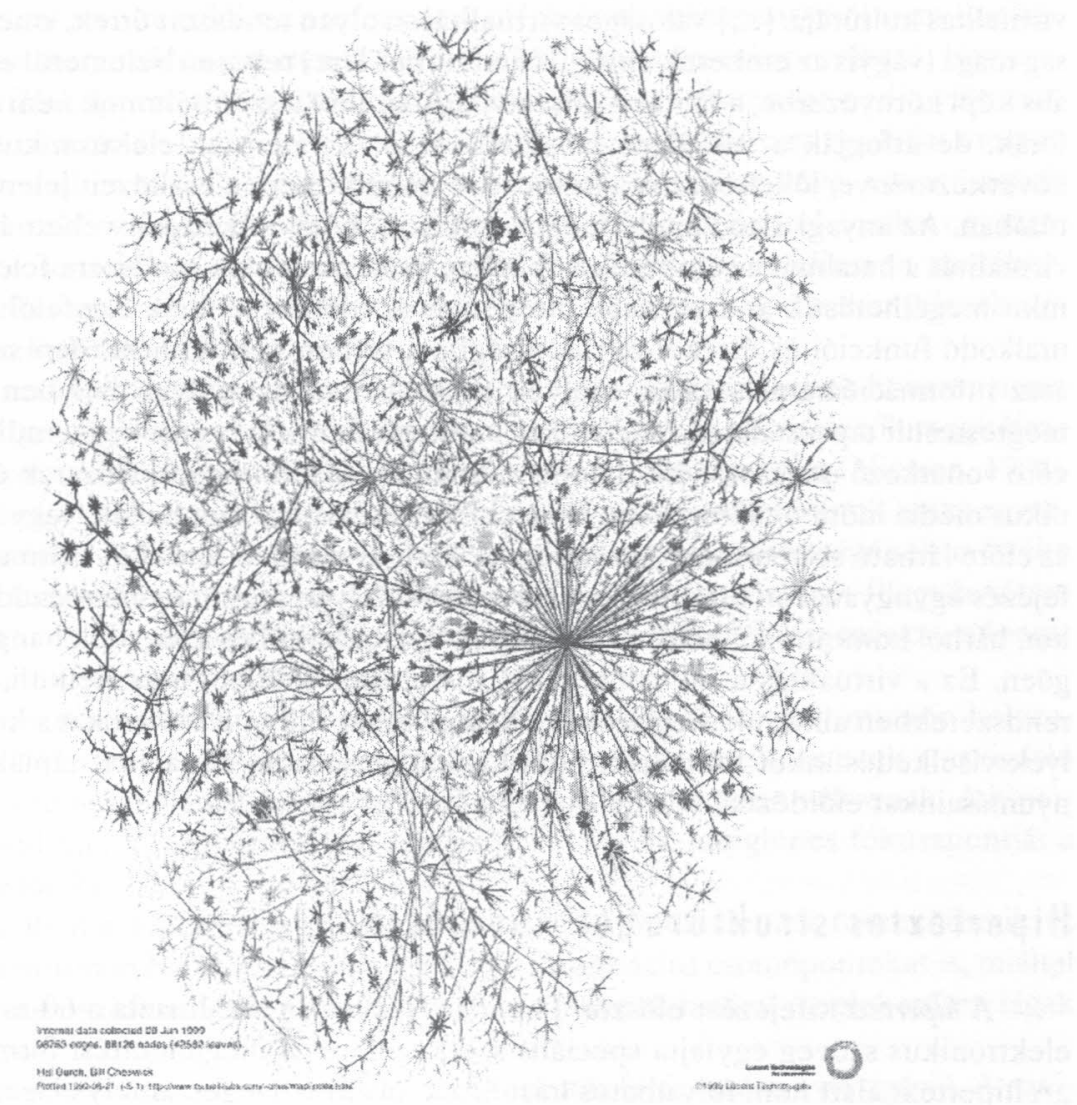

1. abra

Forrás: http://www.cs.bell-labs.com/who/ches/map/

Az internet ezenkívül úgynevezett „kicsi világot” alkotó hálózat is, melynek a glóbusz minden pontjára kiterjedó fizikai architektúrájában az információnak célja eléréséig átlagosan négy kapcsolódási ponton kell áthaladnia (Buchanan, 2003). ${ }^{2}$

Castells „Az információ kora” ${ }^{3}$ címú múvében olyan új tér létrejöttéról beszél, ahol nem a földrajzi távolságok, hanem a hálózaton belüli elrendezôdések a mérvadóak. „A valóságos virtualitás kultúrája, mely egy fokozódóan interaktív és audiovizuális univerzum körül jött létre, mindenütt áthatja a szellemi képzeteket s a kommunikációt, a kultúrák sokféleségét egyfajta elektronikus hipertextben integrálva. A tér és idő - az emberi tapasztalat anyagi alapjai - átformálódtak, midốn az áramlások tere uralkodik a helyek tere fölött s az idốtlen idố váltja fel az ipari korszak óraidejét. 
[...] Az információs paradigma jegyében, midốn az áramlások tere s az idôtlen idó meghaladja a helyeket és megsemmisíti az idốt, új kultúra jött létre: a valóságos virtualitás kultúrája. [...] Valóságos virtualitáson olyan rendszert értek, amelyben a valóság maga (vagyis az emberek anyagi/szimbolikus léte) teljesen belemerül egyfajta virtuális képi környezetbe, a fantázia látszatvilágába, ahol a szimbólumok nem puszta metaforák, de átfogják a valóságos tapasztalatot is. Ez nem az elektronikus médiumok következménye, jóllehet azok a kifejezés elengedhetetlen eszközeit jelentik az új kultúrában. Az anyagi alap, amely megmagyarázza, hogy miképpen veheti át a valóságos virtualitás a hatalmat az emberek képzelete és képzeteinek rendszere felett, nem más, mint megélhetésük az áramlások terében és az idốtlen idóben. Egyfelól a társadalom uralkodó funkciói és értékei egyidejúségben, térben nem érintkezốen szervezôdnek; azaz információáramlásokban, melyek meghaladnak bármilyen helyben-lokalitásban megtestesült tapasztalatot. Másfelól az uralkodó értékek és érdekek a múltra vagy a jövốre vonatkozó utalások nélkül konstruáltatnak, a számítógép-hálózatok és az elektronikus média idốtlen tájképében, ahol a kifejezések vagy azonnaliak, vagy híján vannak az elốre látható sorrendnek. A minden idókból és minden terekból származó összes kifejezés egyugyanazon hipertextben keveredik, folyamatosan újrarendezôdik, és bármikor, bárhol kommunikálható, az adók/küldók érdekeitól és a fogadók hangulatától függôen. Ez a virtualitás a mi valóságunk, mivel eme idốtlen, hely nélküli, szimbolikus rendszerekben alkotjuk meg azokat a kategóriákat s hívjuk elố azokat a képeket, amelyek viselkedésünket formálják, politikánkat gerjesztik, álmainkat táplálják, s lidércnyomásainkat előidézik" (Castells, 1998). ${ }^{4}$

\section{Hipertextes struktúra és navigáció}

A hipertext kifejezést először Theodor H. Nelson alkalmazta a 60-as években, az elektronikus szöveg egyfajta speciális szerkezetére és megjelenítési formájára utalva. „A hipertext alatt nem folyamatos írást értek, olyan szöveget, amely elágazik és választási lehetôségeket kínál az olvasónak, és amely interaktív képernyoón olvasható a legjobban. Általában linkekkel összekötött szövegdarabok soraként képzelhető el, amelyek különbözố útvonalakat biztosítanak az olvasók számára" (Nelson, 1981).

Campbell és Goodman (1988) a hipertext architektúrájának három szintjét különbözteti meg. A hipertext felszíne a prezentációs szint, a felhasználó szeme elé táruló ember-számítógép interfészen megjelenített információdarab, amely mögött ott húzódik az absztrakt gépi szint, a csomópontok és kapcsolóelemek rendszere, továbbá az adatbázisszint. A hiperdokumentumban tárolt információkat a felhasználó csak az ember-számítógép interfészen keresztül, közvetett módon érheti el. A hálózati szervező-

\footnotetext{
${ }^{3}$ A trilógia első kötete, a „Hálózati társadalom kialakulása” (2005) megjelent magyarul is (Budapest: Gondolat-Infonia).

${ }^{4}$ Manuel Castells: The Information Age-Economy, Society and Culture. Oxford: Blackwell Publishers. Vol. III. End of Millennium (1998). Idézi: Nyíri K. (2001).

${ }^{5}$ A hipertext szó ebben a tanulmányban a szöveges, illetve egyéb módon közvetített információs egységek (csomópontok) és az azokat összekötổ kapcsolóelemek (linkek) halmazát jelöli.
} 
dés az absztrakt gépi szinten, ,a számítógépen belül” létezik, a felhasználó mindig csak egy adott csomóponttal vagy annak valamely részletével szembesül.

A hipertext architektúrája az információ elérésének szempontjából nem lineáris, nem folytonos szervezódés, amelynek bármely két pontja összekapcsolható. Egy csomópont többféleképpen is megközelíthetô, a csomópontok sorrendje pedig változtatható az egyes navigációk során, lehetôvé téve, hogy a felhasználó egy gondolat mentén önkényes sorrendben tárja fel a csomópontok tartalmát. Alapjában véve, a mondatok és a „szövegdobozok" szintjén azonban a hipertext is lineáris, a mondatok lexikai egységei ugyanabban a sorrendben jelennek meg, mint más szöveges médiumok esetében. A nem linearitás csak az információs csomópontok összekapcsolódásakor jelentkezik (Dillon, 1996; Espéret, 1996).

A hipertext építésének - talán rövid múltja miatt - még nincsenek konszenzuson alapuló szabályai. Egy-egy adott architektúra azt tükrözi, hogy a kivitelezók megítélése szerint az egyes csomópontok között fennáll-e szemantikai kapcsolat (Nielsen, 1990). Az egyes csomópontok által a hálózatban elfoglalt helynek és a linkeknek nincs egységes jelölési módja. A linkek száma, vagyis a csomópont összekötöttségének mértéke sem a priori meghatározott, hanem az információs egység tartalmának függvényében változhat. Néhány csomópontból rengeteg kapcsolóelem indul ki, míg más csomópontok csupán linkek célpontjaiként szolgálnak.

A hipertextben összekapcsolt csomópontok nem egy fó́ tengely mentén helyezkednek el. A hálózatban párhuzamosan több középpont is létezik, és ezek a navigáció során, ahogy a felhasználó változtatja keresése célját, folyamatosan változnak. A hipertext korlátlanul újra-középpontozható rendszer, amelynek ideiglenes fókuszpontját a felhasználó jelöli ki.

Amennyiben a hipertext egy hálózat része, a kapcsolóelemek összeköthetik az adott dokumentumon belüli és az azon kívül esố információs csomópontokat is, miáltal olyan elektronikus információtestet hoznak létre, melynek határai meglehetôsen tágak és képlékenyek.

A hipertextes szerveződés által definiált hipertér felfedezése a navigáció. A navigáció során a felhasználó az egyik csomópontról a másikra ugrálva bejárja a hiperdokumentumot (McAleese, 1989; Kim és Hirtle, 1995), és eközben összegyújtheti a csomópontokban tárolt információkat (Rouet és mtsai, 1996). Az összekapcsolt, egymást keresztezô utalásokkal, magyarázatokkal ellátott szövegekben a felhasználók bizonyos szabályok szerint, de nem szekvenciális módon navigálnak. A hipertér navigációval történő megismerésének sajátosságai a hipertextes szervezốdés topológiai struktúrájából, valamint abból származnak, hogy a felhasználó a hipertérnek mindig csak az ember-számítógép interfész közvetítette kis szeletével találkozhat.

\section{A hipertér téri sajátosságai}

A tér talán legelfogadottabb koncepciója szerint a tér olyan tartály vagy keret, amelyben dolgok vannak (Nunes, 1991). A tér és a hely hagyományosan a dolgok és a szubjektum fizikai kiterjedése kapcsán kapott értelmet, az új technológiák által közvetített valóságban azonban a tér határvonalai fokozatosan elmosódnak. 
Dieberger (1994) a számítógép fájlrendszerét térnek tekinti, ami lehet dokumentumtér, feladattér, döntési tér vagy bármely olyan tér, amely objektumokat tartalmaz és ezekre az objektumokra vonatkozóan különféle relációkat definiál. Perfetti (1989) a hipertext szövegdobozait a tér pontjainak tekinti, amelyeket a felhasználók bejárhatnak, felfedezhetnek. Foltz (1996) értelmezésében azoknál a felhasználóknál, akik a dokumentumon történô átjutás során az információs csomópontok koherenciájának fenntartása céljából szabályokat állítanak fel a különböző helyzetekben alkalmazandó stratégiákra vonatkozóan, a dokumentum feltárása problémamegoldási folyamattá alakul. A navigáció egy idegen környezet problématerében zajló keresésnek felel meg.

A hiperdokumentumok mint külsố reprezentációk formális értelemben virtuális topológiai tereket definiálnak (Kim és Hirtle, 1995; Dieberger, 1994; Parunak, 1989; Lévy, 1990). A hipertext megfeleltethetố egy irányított gráfnak, amelynek élei a hipertext linkjei, csúcspontjai pedig a csomópontok. Ebben a nem metrikus térben a pontok közötti relációt és a távolságot az összefüggốséggel jellemezhetjük.

A fenti idézetekben a hipertext által definiált tér metaforikus térként jelenik meg, hiszen ez a tér immateriális, és a hipertérben történő mozgás nem fizikai jellegú. K. Memarzia $(1997)^{6}$ értelmezése szerint a kibertér digitális tájainak csak azért vannak geográfiai fogalmakkal értelmezhetố tulajdonságai, mert kifejezetten így tervezték meg és így hozták létre óket. A hipertextnek ez a tulajdonsága azonban nem korlátozódik azokra a területekre, amelyekhez megfelelő „hivatkozási alapot” találhatunk a fizikai világban. A hipertér geometriai formációi közül némelyik kifejezetten a fizikai térból ismerős viszonyokat reprezentálja, és közvetlenül visszavezethetô bizonyos geográfiai mintákra.

Chien és Flemming (1997) az információs és a fizikai tér között fennálló alapvetô különbségeket a következố három kategóriába sorolja: tartalom, struktúra és ember-tér kapcsolat. A geográfiai terek tele vannak stimulusokkal, és szinte az összes érzékszervünkre hatnak, míg az elektronikus tér általában csak vizuális információkat közvetít. Míg a fizikai tér struktúrája stabil, az információs tér dinamikus, szinte állandóan változik. A geográfiai terekben ,elmerülünk”, ténylegesen benne vagyunk, míg az információs téren kívül maradunk, a felhasználó helye a kurzor helye. A hipertextben történó navigáció virtuális mozgás, a virtuális helyváltoztatáshoz tartozó fizikai mozgás a perifériák használata.

A kibertérben a tér és az idő kapcsolata lazul, viszonylagosságuk közvetlen tapasztalattá, formálódik. Az itt és a most, a közel és a távol fogalmai relativizálódnak és fokozatosan egymásba olvadnak. A távolság feloldódik, a hely meghatározatlanná válik, a helyváltoztatás azonnal végbemegy, a jelenlét megsokszorozódhat. A virtuális tér-idő új módon konstruálódott környezetében megváltozik az ember belsố tere, a megismerés horizontja és az emberi akciók szerveződésének elve is.

Az információs társadalom kommunikációs technológiái a megszokott térbeli és idóbeli korlátok ledöntésével újfajta viselkedést tesznek lehetôvé a társadalmi interakciók során is.

\footnotetext{
${ }^{6}$ Dodge és Kitchin (2001). idézi: Memarzia, K. (1997): Towards the Definition and Applications of Digital Architecture. http://www.shef.ac.uk/students/ar/ara92km/thesis/
} 


\section{Hálózati közösségek}

A hálózat alapú virtuális közösségek egyre fontosabb szerepet játszanak az üzleti élet, az oktatás és a szórakozás terén is ( $\mathrm{Li}, 2005)$. Az internet könnyú és széles körú elérhetősége megváltoztatta mind az interperszonális, mind a szervezetek közötti kapcsolatokat. A kibertérnek az elốzố fejezetekben vázolt téri tulajdonságai miatt a felhasználók a navigáció során térben is kimozdulnak azokból a közösségekból, amelyekben hétköznapjaikat élik. A hálózati közösségek tagjaként közös események és cselekvések tagjai lehetnek, megoszthatják érzelmeiket, gondolataikat és tudásukat másokkal. A kibertér így új, online közösségeknek otthont adó társadalmi környezetet teremt.

Rheingold (1994) szerint a virtuális közösségek olyan „társadalmi csoportosulások, amelyek a Hálózatból emelkednek ki, amikor elég sok ember elég sokáig, elegendố emberi érzelemmel folytat nyilvános beszélgetéseket, hogy kialakítsa személyes kapcsolatainak hálózatát a kibertérben”.

A virtuális közösségeknek számos definíciója létezik. Ezeknek a többsége tartalmazza azt a megállapítást, hogy az effajta közösségek - bár a számítógép által közvetített kibertérben léteznek - személyes kapcsolatokon nyugszanak, s témáikat és eseményeiket a résztvevók maguk határozzák meg (Lee és mtsai, 2002). Hozzá kell még tenni ehhez, hogy ezeknek a közösségeknek a kohéziós ereje a nyilvános párbeszéd.

A közösségek létrehozásának jelenlegi gyakorlata szerint az alapítók általában olyan hálózati honlapokat alakítanak ki, ahol a felhasználók regisztráció útján válnak a közösség tagjaivá. Egy-egy online közösség létrehozásának a célja lehet az információcsere valamely szúk szakterületról, a helyi közösségi ügyek megvitatása, beszélgetés különböző problémákról, érdekességekról, vagy például segítségnyújtás is. Az internetes közösségek olyan különbözô célok jegyében szerveződhetnek, mint például a barátkeresés, a vásárlás, a távtanulás vagy a szórakozás.

Hagel és Armstrong (1997) az online közösségeket annak alapján csoportosítják, hogy milyen szükségletet elégítenek ki, s ezen az alapon az érdeklódés, a kapcsolat, a fantázia és a tranzakció típusaiba sorolják a közösségeket. Ezzel a csoportosítással az irodalomban fellelhetố késóbbi klasszifikációk is összecsengenek (Carver, 1999; Bressler, 2002).

Egyes kutatások azt mutatják, hogy a kibertéri élet valódi közösségi élmény érzetét nyújtja (Rafaeli és Sudweeks, 1996). A virtuális világban azonban a jelenlét csak távjelenlét, és a kibertér több érzékszervünk felé nem közvetít semmiféle információt. Az interaktív virtuális környezetben alakuló közösségekben - legyenek azok bármilyen fejlettek is - számos emberi szükséglet kielégítése jelenleg megoldhatatlan, ezért egyes kutatók szerint az online közösségeket nem lehet tényleges közösségeknek tekinteni, mivel nem tudják reprodukálni az együtt élő közösségek szerepét és jelentőségét (Papadakis, 2003).

A virtuális közösségek legelterjedtebb formája a szöveges üzenetek váltásán alapuló, úgynevezett text-based reality. Ez a kifejezés mindazokat a közösségeket jelöli, amelyeket az interneten futó hipertextes szerveződések kapcsolnak össze. Ebbe a kategóriába tartozik a hálózati csevegés (chat) és a fórum. Számos csevegőprogram speciális lehetốségeket biztosít a mások által nem látható, a telefonhoz hasonlóan hangélményt is nyújtó vagy akár képet is közvetítő személyes kommunikációra. A csevegés többnyire 
a regisztrált felhasználók szúkebb körén belül bonyolódik le (néha csak a közös beleegyezéssel kiválasztott tagokra korlátozódva), de vannak bárki által látogatható csevegóközösségek is. Ma már olyan $3 D$ csevegófórumok is elérhetók, ahol a felhasználó megépített városokban, háromdimenziós figurákkal csatangolhat.

A fórumok egy-egy témakör megvitatására szerveződött közösségek.

A helyi hálózati közösségek a földrajzilag is meghatározott közösségeket szolgálják, az érdeklődési közösségek pedig egy-egy témakör köré szerveződnek. Mindkét típus kommunikációs eszköze lehet elektronikus levelezés és csevegés egyaránt.

A text-based reality egyik legrégibb, speciális fajtájához tartoznak a sokfelhasználós „erôdítmények” (multi-user dungeons, MUDs). Ezek több párhuzamos felhasználó számára kialakított komplex kalandprogramok, amelyek kizárólag szöveges érintkezésen alapulnak. Ebból kifolyólag nagyobb szerepet játszik bennük az absztrakció, mint a grafikus virtuális környezetekben. Turkle (1995) és Bromberd (1996) kutatásai szerint a $M U D$-ok nem csupán a játék színterei, hanem szociális funkciókat ellátó emocionális környezetek, amelyek valós problémák megoldására szolgálnak. A kibertérben folyó társadalmi érintkezések McRea (1997) szerint is jelentôs hatással vannak az egyes emberekre, akiknek akár az értékrendjét is megváltoztathatják.

A virtuális városok tematikusan összefüggő csoportokba szerveződött honlapokból épülnek fel. A felhasználók különféle fórumokon, valamint csevegóprogramok segítségével érintkeznek egymással.

\section{A kibertéri tulajdonságok hatása a közösségekre}

A közösségek hagyományos felfogása szerint a hely meghatározó tényezôje a szociális interakciók létrejöttének és a személyes kötódések kialakulásának (Rheingold, 1993). A 20. század - nagyrészt a távközlési technológiák igen gyors fejlódésének tulajdoníthatóan - robbanásszerú változást hozott a közösségek helyi meghatározottságban. A kibertér az elôzốekben vázolt téri tulajdonságai révén olyan globális és globalizáló médium, amely megfelelố eszközökkel bárhonnan elérhetố, és az emberek valós térbeli közelsége nélkül is alkalmas közösségek kialakítására, spontán önszervezôdés útján (Rheingold, 1994; Castells, 2005).

Ma már igen sok tudományos kutatási eredmény bizonyítja, hogy a kibertér nemcsak az információáramlásban játszik nagy szerepet, hanem mind az online, mind pedig az offline társadalmi kapcsolatok alakulását is jelentốsen befolyásolja.

A kibertérben megváltozik a közösségek szervezôdési elve. A virtuális világban a testetlen ének létezési formája a kommunikáció, így a kibertér használói arra építik a közösséget, hogy a tagok mit gondolnak, mondanak, hisznek, és mi érdekli óket. Ezek a közösségek nem tagjaik egymás mellett élésére, külsô megjelenésére vagy egyéb materiális tényezókre épülnek, hanem a bennük részt vevố egyének egymással folytatott kommunikációján alapulnak. A kibertérben az emberek szabadon választhatják meg interakcióik partnerét, maguk alakíthatják ki saját közösségeiket, viselkedési normáikat, értékeiket és kötôdéseiket. Ahogy Turkle (1995) fogalmaz: „a kibertér az a hely, ahol a személyiség és a szociális interakciók szabályai építettek, nem kapottak". 
Az online hálózati közösség és a hagyományos közösség számos szociológiai jellemvonása azonos. Mindkettố formálja a személyiséget, kialakítja normáit és hierarchiai rendszereket épít ki (Papadakis, 2003). A kibertér képes befolyást gyakorolni az éntudatra és ezáltal a közösségre. A kibertér egyrészt azáltal módosítja az éntudatot, hogy a felhasználó kiléphet valós testéból és egy - vagy akár több - virtuális alakot ölthet, az anyagtalan térben túllépve a magatartását befolyásoló számos fizikai tulajdonságon (Haraway, 1991; Stone, 1991). Másrészt az anonimitás oltalma alatt a hálózati közösségek résztvevői ôszintébbek, nyitottabbak egészen intim kérdésekben is (Wellman és Giulia, 1999).

A virtuális én kialakításának egy másik fontos meghatározó eleme az a tény, hogy a felhasználó kimozdulhat megszokott társadalmi környezetéból. A kibertérben a „kiberkalandor” a társadalmi emlékezetról megfeledkezve, a valós világban várható szankciók nélkül hághatja át a szúk társadalmi környezet normáit (Adams, 1997; Wilbur, 1997). Ezért a rend és az ellenốrzés fenntartása érdekében a hálózati közösségek is különbözố taktikákat alkalmaznak (Barzilai-Nahon és Neumann, 2005). Ilyen lehet például a regisztráció, továbbá bizonyos szoftverek szúrése és blokkolása. A fenntartható információáramlás egyik legfóbb pillérének azonban a virtuális környezetben jelenleg az önszabályozás tekinthetô. Az erôs kohéziós erôvel rendelkező csoportokban erôsebben nyilvánul meg az önreguláció, olyan eljárások alkalmazásával, mint például a szabályozókkal történő együttmúködés vagy a szabályszegések szankcionálása (Barzilai-Nahon és Neumann, 2005).

\section{A közösségek térkeresése}

Az együtt élő közösségek „,helye” földrajzilag meghatározott fizikai entitás. „Ha helyen többet értünk, mint puszta geodéziai koordinátákat, úgy csakhamar belátható, hogy a helyek-helységek társadalmi konstrukciók. A szülófalu, a kedves kisváros, a szépséges természeti táj: valamennyien emlékekból, ismeretségekbó1, tevékenységekból épülnek föl. [...] A helyet fogalmilag találkozási pontként, tevékenységi terek, kapcsolatok és eleven viszonyok, befolyások és mozgások kereszteződési pontjaként ragadhatjuk meg" (Nyíri, 1998). A helyek különböző asszociációkat és érzelmeket idéznek elố, társadalmi normákat tükröznek, s meghatározott szokások és tevékenységek köthetók hozzájuk.

A kibertér tényleges megjelenítését, az interfészeket is úgy tervezik meg, hogy a valós világ téri formáira hasonlítsanak. Úgy túnik, hogy a kibertér használói új „, helyérzést", új tériséget keresnek (Poster, 1995). A kibertérben élő társadalmi kapcsolatoknak - a kibertér „helynélkülisége” ellenére - valójában a térbeliség ad keretet. Foster (1997) kutatásai szerint volt olyan virtuális közösség, amely azért bukott el, mert tagjainak nem nyújtotta a „hely” érzését.

Ezt támasztja alá az is, hogy a kibertérról olyan szavak használatával beszélünk, mint a szoba, hely, szupersztráda, szörfözés, navigáció vagy épités. A téri metaforák rendszeres használata azt sugallja, hogy a hipertext rendelkezik téri tulajdonságokkal, van például mélysége és nagysága. Az erre irányuló kutatásokat áthatja az a feltételezés, hogy a felhasználók téri terminusok alapján konceptualizálják a hipertextet. Parunak (1989) 
szerint a hipertextben történő navigáció megközelítóen azokat a feladatokat és stratégiákat foglalja magában, amelyeket a geográfiai térben folyó útkeresési tevékenység, és az emberek úgy navigálnak a hipertérben, mintha a fizikai világban mozognának.

A hipertext mentális reprezentációjának felépítéséhez szükség van egy olyan területre, amely - metaforák használata révén - a folyamat alapjául szolgálhat (Rouet és mtsai, 1996). A metaforák lényege valamely területnek egy másik szempontjából történő megtapasztalása és megértése, az absztrakt fogalmak közvetlenül érzékelhetô élményekhez kapcsolása. A metafora - hétköznapi értelmezésével ellentétben - nem retorikai díszítőelem, hanem a világ konceptualizálását szolgáló alapvetố eszköz (Lakoff, 2003).

Mivel téri tapasztalatainkat direkt módon értjük meg, azok metaforikus forrásterületként szolgálhatnak (Lakoff, 1987). Tágabb értelmezésben többször is felmerült az a gondolat, hogy az absztrakt következtetések nagy része téri relációk és következtetések metaforizált változata (Lakoff, 1992; Gibbs és Colston, 1995). A tériesítéssel az inherens téri tulajdonságokkal nem jellemezhetố adatok és információk téri keretrendszerben értelmeződnek, így a valós térben nyert kézzelfogható tapasztalataink metaforikus projekciójával értelmezhetjük a hipertext szerveződését is. ${ }^{7}$

A virtuális világban szerzett tapasztalatainkat alapvetốn térbeli élményként éljük meg (Taylor, 1997).

\section{A kiberközösségek hatása az együtt élő közösségekre}

Az információs és kommunikációs technológiák fejlôdése és a kibertérben zajló események nem hagyhatják érintetlenül a társadalom folyamatait, hiszen az online és az offline folyó élet egyetlen - és talán oszthatatlan - valóságot alkot. Az együtt élő közösségek megmaradnak, azonban a kibervilágban - számos hagyományos kulturális és társadalmi interakciós szabályt felrúgva - új közösségekhez is csatlakozhatunk. „A hálózott individuum: sajátos tájékozódásai, kapcsolódásai által megkülönböztethetô egyéniség, aki ugyanakkor állandó kommunikatív összeköttetésben áll szúkebb-tágabb virtuális közösségével" (Nyíri, 2001).

A hálózati közösségek segíthetik, támogathatják a már létezố, együtt élố társadalmi csoportok életét, ugyanakkor számos olyan közösség is létezik az interneten, amelynek a tagjai nem ismerik, és nem is akarják személyesen megismerni egymást. A „negatív kórus" szerint a kibertér gyengíti, sốt a radikális hangok szerint fel is válthatja az együtt élő közösségeket azáltal, hogy a földrajzi közelség helyett a közös érdeklődésen alapuló csoportosulás lehetôségét kínálja. Az új információs és telekommunikációs eszközök közvetettebbé teszik az emberi érintkezést, s így az együtt élő társadalom szint-

\footnotetext{
${ }^{7}$ A hipertextben történố navigációhoz is tartozik azonban fizikai mozgás, nevezetesen a perifériák használata. Ez a mozgás a hipertéren kívül valósul meg, és maga a fizikai mozgás (az egér mozgatása) eredményezi a kurzor helyének, azaz a hipertérben navigáló felhasználó által elfoglalt helynek a megváltozását. Az informatikai környezet manipulációja meglehetôsen kevés és primitív mozgás (az egér mozgatása, kattintások és a billentyưzet használata) révén történik, amelyeknek az eredménye azonban meglehetôsen változatos (ugyanazzal a kattintással feltárulhat egy új ablak, vagy csak átugorhatunk egy sort), ezért a fizikai mozgás és annak eredménye között nincs kölcsönösen egyértelmú megfelelés.
} 
jén az egyén kapcsolataitól megfosztottá és egyre antiszociálisabbá válhat (Cummings és mtsai, 2002; Kiesler és mtsai, 2002; Putnam, 2001). Ugyanakkor a társadalomtudósok körében már Ferdinand Tönnies 1887-ben megjelent „Közösség és társadalom” címú könyvének fogadtatása óta zajlik a vita a közösségek felbomlásáról, hiszen a modern társadalmakban az egyén egyre inkább kikerül szúk földrajzi környezetének meghatározottságából. A helyi közösségeket jellemzó szoros kötelékeket felváltották a rugalmas, laza kapcsolati struktúrák, és az egyén a nyitott társadalmakban általában egyszerre több hálózatnak és csoportnak is a tagja (Wellman, 2001). Azokat a konfliktushelyzeteket, amelyek abból származnak, hogy valaki egyidejúleg több közösséghez tartozik, a multiközösségben élő egyén általában kezelni tudja (Anderson, 1999). Az online közösségek megjelenésével a felhasználó számos már meglevő együtt élő közössége mellé érdeklődése és szükségletei alapján - még továbbiakat is választhat. A kérdés itt az, hogy az egyén kezelni tudja-e az egyidejúleg fennálló hálózati és a földrajzi közösségi tagságából fakadó konfliktushelyzeteket.

A fenti megállapításokkal egybehangzóan számos tanulmány érvel amellett, hogy az internet erósíti, kiegészíti az együtt éló közösségek társadalmi kapcsolatait, és támogatja a kibertéren kívüli szociális hálót (Toffler, 2001; Welmann és mtsai, 2001; Kavanaugh és mtsai, 2003).

Más értelmezésben a virtuális és a valós világ szétválasztása helytelen, hiszen az elóbbi inkább a második kiterjesztéseként értelmezhetô, és ekként is funkcionál (Wellmann és Giulia, 1999). Az online kommunikáció is a valóság része, az interakciók résztvevôi valóságos emberek. A virtuális társadalomban a virtualitás inkább a valóság egy újabb dimenziója, mintsem attól függetlenül létezó entitás (Lévy, 1998). A virtuális közösségek a társadalom részét képezik, s így részesei a társadalmi változásoknak és fejlôdési folyamatoknak.

\section{Összefoglalás}

A közösségalkotás szempontjából a kibertérben sokkal fontosabbak a szemantikai jellemzó vonások, mint a földrajzi távolság. A virtuális valóságban azonban a technológiai fejlődéssel párhuzamosan egyre markánsabban megfigyelhetô az újfajta térkeresés és helyalkotás.

Amikor az ember végre test nélkülivé válhat, a fejlődés útja egyre inkább a $3 D$ virtuális testek felöltésének irányába mutat. Amikor a „tér nélküli” térból tetszés szerinti helyeket hozhatunk létre, a kibertér egyre inkább a hagyományos geográfiai mintázatokra kezd hasonlítani.

„Az ember sajátos módon érzékeny a helyekre [...] magukat a funkciókat helyekhez kötjük, s az új világ, már az internetezéssel is, elszakít a helyektól... Kérdés, mennyire vagyunk képesek erról leszokni” (Pléh, 2001).

A fentiek alapján a közösségek fejlődése elsősorban a kétféle tér folyamatos kölcsönhatásának eredményeként valósul meg, s kevésbé valószínú azoknak a félelmeknek a beigazolódása, amelyek a kiberközösségeknek az együtt élók közösségekre gyakorolt egyoldalú, és a technológiai fejlődéssel egyre erôsödố szétziláló hatásával kapcsolatban gyakran megfogalmazódnak. A közösségek castellsi „valóságos virtualitása” 
és a geográfiai helyek, valamint a rájuk épülő közösségek kibertéri entitásokkal történô lényegi helyettesítése egyelốre - a jelenlegi technológiák biztosította „helyérzés” és távjelenlét mellett - negatív utópiának túnik.

\section{Irodalom}

Adams, P. (1997): Computer Networks and Virtual Place Metaphors. Geographical Review, 87.

Barzilai-Nahon, K. - Neumann, S. (2005): Bounded in Cyberspace: An Empirical Model of SelfRegulation in Virtual Communities. Proceedings of the 38th Hawaii International Conference on System Sciences.

Bressler, S. E. (2000): Communities of Commerce: Building Internet Business Communities to Accelerate Growth, Minimize Risk, and Increase Customer Loyalty. McGrawhill.

Bromberg, H. (1996): Are MUDs Communities? Identity, Belonging and Consciousness. In: Cultures of Internet: Virtual Spaces, Real Histories, Living Bodies. London: SAGE Publications.

Buchanan, M. (2003): Nexus, avagy kicsi a világ. A hálózatok úttöró tudománya. Budapest: Typotext.

Campbell, B. - Goodman, J. M. (1988): HAM: A General Purpose Hypertext Abstract Machine. Communications of the ACM, 7.

Carver, C. (1999): Building a Virtual Community for a Tele-Learning Environment. IEEE Communication Magazine, 3.

Castells, M. (2005): A hálózati társadalom kialakulása. Budapest: Gondolat-Infonia.

Chien, S. - Flemming, U. (1997): Information navigation in generative design system. CAADRIA'97: Proceedings of The Second Conference on Computer Aided Architectural Design Research in Asia. Taiwan.

Cummings, J. - Butler, B. S. - Kraut, R. (2002): The Quality of Online Social Relationships. Communications of the ACM, 45.

Dieberger, A. (1994): Navigation in textual virtual emvironments using a city metaphor. Unpublished Doctoral Dissertation. Vienna: Vienna University of Technology.

Dillon, A. (1996): Myths, misconcepts, and an alternative perspective on information usage and the electronic medium. In Rouet, J. - Levonen, J. J. - Dillon, A. - Spiro, J. R. (eds.): Hipertext and Cognition. Mahwah: Lawrence Erlbaum Associates.

Dodge, M. - Kitchin, R. (2001): Mapping Cyberspace. London: Routledge.

Espéret, E. (1996): Notes on hipertext, cognition and language. In Rouet, J. - Levonen, J. J. Dillon, A. - Spiro, J. R. (eds.): Hipertext and Cognition. Mahwah: Lawrence Erlbaum Associates.

Foltz, W. P. (1996): Comprehension, coherence, and strategies in hipertext and linear text. In Rouet, J. - Levonen, J. J. - Dillon, A. - Spiro, J. R. (eds.): Hipertext and Cognition. Mahwah: Lawrence Erlbaum Associates.

Foster, D. (1997): Community and Identity in the Electronic Village. In Porter, D. (ed.): Internet Culture. London: Routledge.

Gibbs, R. W. Jr. - Colston, H. L. (1995): The cognitive psychological reality of image schemas and their transformation. Cognitive Linguistics, 6.

Hagel, J. - Armstrong, A. (1997): Net Gain: Expanding Markets through Virtual Communities. Harvard Business School Press, Boston: Mass.

Haraway, D. (1991): Simians, Cyborgs and Women. London: Free Association Press.

Kavanaugh, D. D. - Reese, J. C. - Rosson, M. B. (2003): Weak Ties in Networked Communities. In Wulf, V. (ed.): Communities and Technologies. Kluwer Academic Publishers.

Kiesler, S. - Kraut R. - Cummings, J. - Boneva, B. - Helgeson, V. - Crawford, A. (2002): Internet Evolution and Social Impact. In Watson, R. (ed.): The E-Business Handbook. New York: CRC Press. 
Kim, H. - Hirtle, S. C. (1995): Spatial metaphors and disorientation in hipertext browsing. Behaviour \& Informational Technology, 4.

Lakoff, G. (1992): The Contemporary Theory of metaphor. http://www.ac.wwu.edu/ market/semiotic/lkof_met.html

Lakoff, G. (1987): Women, fire, and dangerous things. Chicago: The University of Chicago Press.

Lee, L. S. F. - Vogel, D. - Limayem, M. (2002): Virtual Community Informatics: What We Know and What We Need to Know. Proceedings of 35th Hawaii International Conference on System Sciences. http://csdl2.computer.org/comp/proceedings/hicss/2002/1435/08/14350214b.pdf

Lévy, P. (1990): Les technologies de l'intelligence. L'avenir de la pensée à l'ère Informatique. Paris: La découvetre.

Lévy P. (1998): Becoming Virtual. Reality in the Digital Age. New York: Plenum trade.

McAleese, R. (1989): Hipertext theory into practice. Norwood: Ablex Publishing Corporation.

Li, X. (2005): Buddy-finding in the mobile environment. Technovation, 25.

McRae, S. (1997): Flesh Made Word: Sex, Text and the Virtual Body. In Porter, D. (ed.): Internet Culture. London: Routledge.

Mészáros, R. (2001): A kibertér társadalomföldrajzi megközelítése. Magyar Tudomány, 7.

Nelson, T. H. (1981): Literary machines. Swarthmore: Self-published.

Nielsen, J. (1990): Hypertext and Hypermedia. Boston: Academic Press.

Nunes, J. (1991): Geographic space as a set of concrete geographical entities. In Mark, D. M. Frank, A. U. (eds.): Cognitive and Linguistic aspects of geographic space. Doldrecht: Kluwer.

Nyíri K. (1998): Globális társadalom és lokális kultúra a hálózottság korában.

Nyíri K. (2001):Castells, The Information Age.21st.century.phil-inst.hu/2001_dec_konf/NYIRI.pdf

Nyíri K. (2001): Mobil információs társadalom. Visszatérés a gyökerekhez. http://wap.phil-inst.hu/2001_maj/Nyiri_prez/nyiri_text.htm

Parunak, H. (1989): Hypermedia topologies and user navigation. In: Hipertext'89 proceedings. New York: Association for Computing Machinery.

Perfetti, A. C. (1989): Text and hipertext. In: Hipertext'89 proceedings. New York: Association for Computing Machinery.

Papadakis, C. M. (2003): People Can Create a Sense of Community in Cyberspace. http://www.sri.com/policy/csted/reports/sandt/it/Papadakis_IT_virtual_communities_ issue_brief.pdf

Pléh Cs. (2001): Új kommunikáció - új gondolkodás?

http://cogsci.bme.hu/csaba/docs/magyar/informacios\%20tarsadalom/uj_kommunikacio.doc

Poster, M. (1995): The Second Media Age. Oxford: Polity.

Putnam, R.(2001): Bowling alone: the collapse and revival of American community. New York: Simon and Schuster.

Rafaeli, S. - Sudweeks, F. (1996): Networked Interactivity. Journal of Computer Mediated Communications, 2. http://www.ascusc.org/jcmc/vol2/issue4/rafaeli.sudweeks.html

Rheingold, H. (1993): The Virtual Community: Homesteading on the Electronic Frontier. New York: Addison-Wesley.

Rheingold, H. (1994): A Virtual Community. Finding a Connection in a computerized world. Cambridge: MIT Press.

Rheingold, H. (1994): The Virtual Community: Homesteading on the Electronic Frontier. London: Secker \& Warburg.

Rouet, J. - Levonen, J. J. - Dillon, A. - Spiro, J. R. (1996): An introduction to hipertext and Cognition. In Rouet, J. - Levonen, J. J. - Dillon, A. - Spiro, J. R. (eds.): Hipertext and Cognition. Mahwah: Lawrence Erlbaum Associates.

Stone, A. S. (1991): Will the Real Body Please Stand-up?: Boundary Stories About Virtual Cultures. In Benedikt, M. (ed.): Cyberspace: First Steps. Cambridge: MIT Press. 
Tönnies, F. (1983): Közösség és társadalom. Budapest: Gondolat.

Turkle, S. (1995): Life on the screen:Identity int he age of the Internet. New York: Simon and Schuster.

Taylor, J. (1997): The Emerging Geographies of Virtual Worlds. The Geographical Review, 87.

Toffler, A. (2001): A harmadik hullám. Budapest: Typotex.

Wellman, B. - Giulia, M. (1999): Net surfers don't ride alone: Virtual communities as communities. In Wellman, B. (ed.): Networks in the Global Village. Westview Press.

Wellman, B. - Hasse, A. Q. - Witte, J. - Hampton, K. N. (2001): Does the Internet Increase, Decrease or Supplement Social Capital? Social Networks, Participation, and Community Commitment. The American Behavioral Scientist, 45.

Wellman, B. (2001): The Persistence and Transformation of Community: From Neighbourhood Groops to Social Networks. Report to the Law Commission of Canada.

http://www.chass.utoronto.ca/ wellman/publications/lawcomm/lawcomm7.PDF

Wilbur, S. P. (1997): An Archaeology of Cyberspaces: Virtuality, Community, Identity. In Porter, D. (ed.): Internet Culture. London: Routledge. 